\title{
Methylene blue-related corneal edema and iris discoloration
}

\author{
Edema de córnea e descoloração de íris associados ao azul de metileno
}

\author{
Ozgur Bulent Timucin $^{1}$, Mehmet Fatih Karadag ${ }^{1}$, Mehmet Emin Aslanci ${ }^{2}$, Mehmet Baykara ${ }^{2}$
}

\begin{abstract}
We report the case of a 70-year-old female patient who developed corneal edema and iris discoloration following the inadvertent use of $1 \%$ methylene blue instead of $0.025 \%$ trypan blue to stain the anterior capsule during cataract phacoemulsification surgery. Copious irrigation was performed upon realization of incorrect dye use. Corneal edema and iris discoloration developed during the early postoperative period and persisted at 24-months follow-up. However, keratoplasty was not required. The intracameral use of $1 \%$ methylene blue has a cytotoxic effect on the corneal endothelium and iris epithelium. Copious irrigation for at least $30 \mathrm{~min}$ using an anterior chamber maintainer may improve outcomes.
\end{abstract}

Keywords: Phacoemulsification; Corneal edema; Iris; Methylene blue; Anterior eye segment; Drug effects; Adverse effects; Ophthalmic solutions; Case reports

\section{RESUMO}

Paciente do sexo feminino com 70 anos de idade desenvolveu edema da córnea e descoloração da íris após o uso inadvertido de $1 \%$ de azul de metileno em vez de 0,025\% de azul tripano para corar a cápsula anterior do cristalino durante a cirurgia de catarata por facoemulsificação. Foi realizada irrigação abundante quando detectou-se que o corante incorreto tinh a sido usado. Edema da córnea e descoloração íris que ocorreu no período pós-operatório precoce persistiu durante 24 meses de seguimento; no entanto, a ceratoplastia não foi necessária. O uso intracameral de $1 \%$ de azul de metileno tem efeitos citotóxicos sobre o endotélio da córnea e epitélio da íris. A irrigação abundante durante pelo menos 30 minutos, utilizando um mantenedor de câmara anterior pode resultar em um prognóstico melhor.

Descritores: Facoemulsificação; Edema da córnea; Segmento anterior do olho; Iris/efeitos de drogas; Azul de metileno/efeitos adversos; Soluções oftálmicas; Relatos de casos

\section{INTRODUCTION}

Several dyes are used to stain the anterior capsule during cataract surgery, including indocyanine green, sodium fluorescein, rose bengal, gentian violet, and trypan blue ${ }^{(1)}$. Trypan blue $(0.025 \%)$ is generally considered safer than other dyes because it does not cause postoperative inflammation, endothelial dysfunction, residual staining of the anterior chamber, or iris staining ${ }^{(2)}$. The use of inappropriate dyes or dyes at inappropriate concentrations may result in severe ocular toxicity ${ }^{(3,4)}$. We report a case of inadvertent administration of $1 \%$ methylene blue for capsule staining during cataract surgery. Limited effects of methylene blue toxicity were observed contrary to expectations with no evidence of bullous keratopathy ${ }^{(5,6)}$. We discuss the possible reasons for the limited toxic effects observed following the administration of $1 \%$ methylene blue into the anterior chamber.

\section{CASE REPORT}

We report a case of inadvertent injection of $0.1-0.2 \mathrm{ml}$ of $1 \%$ methylene blue into the anterior chamber instead of 0.025\% trypan blue for anterior capsule staining during phacoemulsification in a 70-year-old female patient with a mature cataract in the left eye. On injection of the dye into the anterior chamber, the administering surgeon observed that the blue dye was darker than normal and the cornea was gradually staining blue. When it was understood that the incorrect dye had been used to stain the anterior capsule on questioning the nurse, the area was copiously irrigated with balanced salt solution for approximately 30 min using an anterior chamber maintainer (ACM). After the capsule was stained and the setting became sufficiently transparent, surgery proceeded without further complications, and a foldable acrylic intra ocular lens was implanted in the capsular bag. The following day, eye examination revealed +3 diffuse corneal edema, a visual acuity of approximately 0.05 , and an intraocular pressure of $14 \mathrm{mmHg}$. Hourly topical steroid and antibiotic therapies were initiated. After one week, eye examination findings persisted. Eye examination at one month revealed +1 central corneal edema and 3/10 visual acuity (Figures 1 and 2). On eye examination at 24 months, corneal edema had almost entirely resolved, although subtle stromal haze and iris discoloration persisted, and the central corneal thickness had thickened $(560 / 510 \mu \mathrm{m})$ compared with that of her right eye (Figures 3 and 4).

\section{DISCUSSION}

Methylene blue and trypan blue, which are used in the operating theatre, are generic brands stored in multiple-use bottles. Methylene blue is maintained in the operating theatre for multiple uses, including skin marking during eyelid surgery (blepharoplasty) and scleral marking during scleral buckling. Trypan blue is commonly used to stain the anterior capsule in challenging cataract cases. Trypan blue selectively stains the basal membrane of the anterior capsule. Methylene blue stains the anterior capsule in a similar manner.

The effects of inadvertent intraocular injection of methylene blue have not been discussed in detail in previous literature. A number of studies have performed intrachamber administration of various dyes to establish the safety and efficacy of dye injections ${ }^{(3,4)}$. These studies demonstrated no corneal endothelial damage on the intrachamber

Submitted for publication: March 11, 2015

Accepted for publication: May 2, 2015

${ }^{1}$ Department of Ophthalmology, Istanbul Hospital, Van, Turkey.

2 Department of Ophthalmology, School of Medicine, Uludag University, Bursa, Turkey.

Funding: No specific financial support was available for this study.

Disclosure of potential conflicts of interest: None of the authors have any potential conflicts of interest to disclose.

Corresponding author: Ozgur Bulent Timucin. Van Özel İstanbul Hastanesi. Oftalmoloji Bölümü Merkez/Van - 65100 - Turkey - E-mail: bulenttimucin@gmail.com 


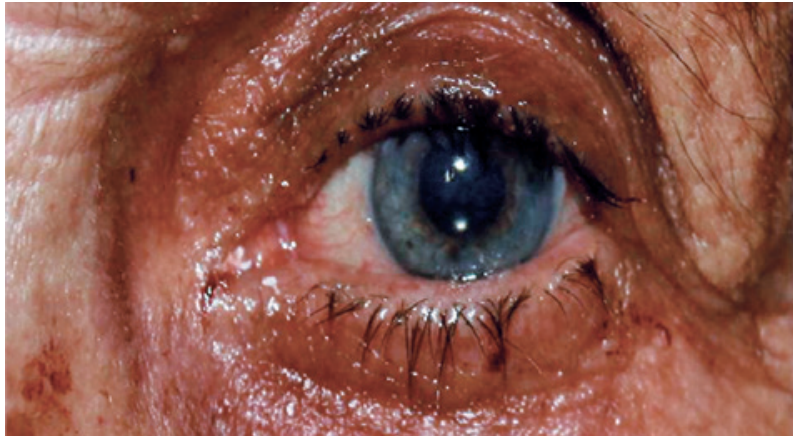

Figure 1. Central corneal edema on postoperative day 1.

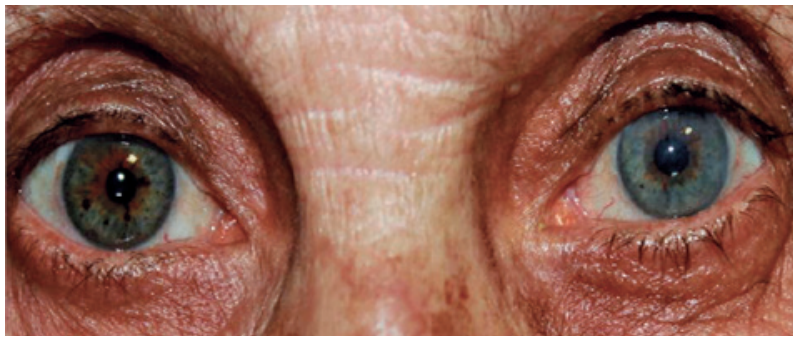

Figure 2. Persistent central corneal edema and iris discoloration at one month postoperatively.

injection of $0.05 \mathrm{ml}$ of $0.2 \%$ methylene blue for 1 min by transmission electron microscopy. Corneal endothelial toxicity begins to occur with intrachamber administration of $0.5 \%$ methylene blue ${ }^{(3)}$. A concentration of $0.1 \%$ is sufficient to stain the anterior capsule without causing ocular toxicity or staining of adjacent structures ${ }^{(3)}$.

We identified similar publications in the literature reporting the inadvertent use of methylene blue and found one case that developed bullous keratopathy after persistent corneal edema, resulting in keratoplasty, and one case that developed persistent corneal edema and endophthalmitis with progression to corneal failure ${ }^{(5,6)}$. Based on previously reported cases, we predicted the definitive development of bullous keratopathy because of endothelial insufficiency in this case. However, we determined bullous keratopathy had not developed and that a functional level of vision had been preserved after a 24-month follow-up period. Copious irrigation of the anterior chamber using ACM may have protected against the expected development of bullous keratopathy. The anterior chamber was irrigated throughout the surgery using a 20-G ACM attached to a balanced salt solution bottle. In contrast to previously reported similar cases, irrigation of the anterior chamber using ACM for at least 30 min may have protected the corneal endothelium in our case. We believe that the cornea may have been partially protected by the treatment method utilized in this case, a clinical scenario that may be encountered by any surgeon. However, this explanation for the improved outcome in this case requires validation in experimental animal models. Therefore, ACM may be an important tool in the management of inadvertent intraocular injection of toxic dyes by facilitating anterior

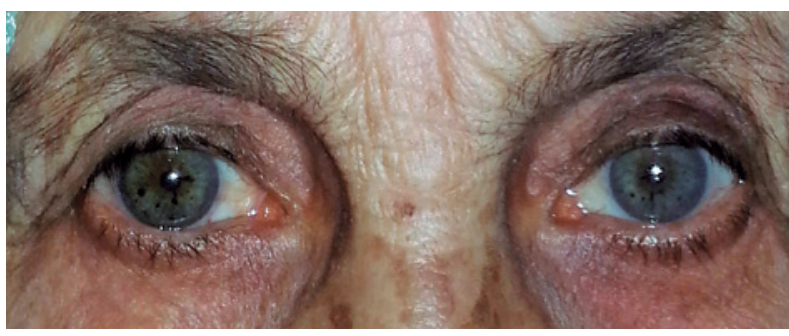

Figure 3. Complete resolution of corneal edema clinically observed at 24 months postoperatively.

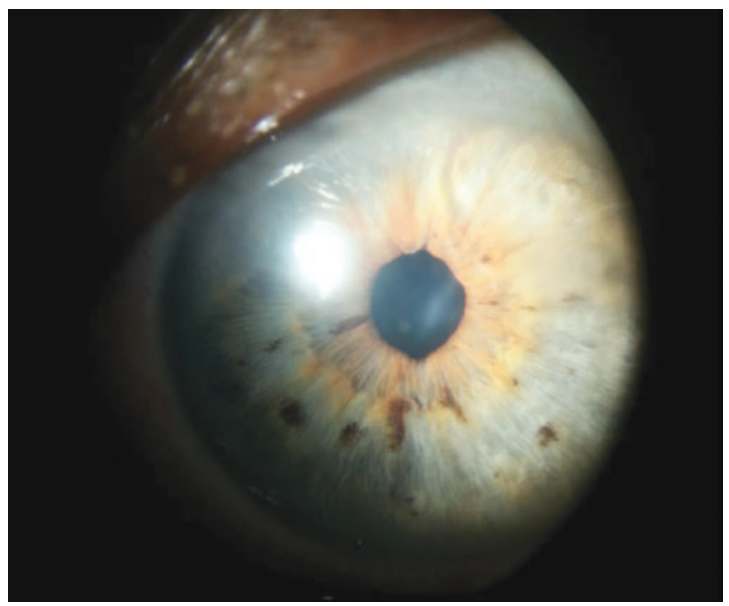

Figure 4. Complete resolution of corneal edema clinically observed at 24 months postoperatively.

chamber washout and reducing iatrogenic injury of the iris and corneal endothelium.

A number of minor precautionary measures in the operating room may help avoid the inadvertent use of methylene blue instead of trypan blue, including labeling methylene blue bottles in an obvious manner, the use of different cap colors, and storing methylene blue in a different location to trypan blue.

\section{REFERENCES}

1. Dada VK, Sharma N, Sudan R, Sethi H, Dada T, Pangtey MS. Anterior capsule staining for capsulorhexis in cases of white cataract: comparative clinical study. J Cataract Refract Surg. 2004;30(2):326-33.

2. Marback EF, Freitas LL, Fernandes FP, Branco BC, Belfort R Jr. Anterior capsule staining using $0.025 \%$ trypan blue in cataracts without red reflex. Arq Bras Oftalmol. 2001; 64(4):333-5.

3. Chang YS, Tseng SY, Tseng SH, Chen YT, Hsiao JH. Comparison of dyes for cataract surgery. Part 1: cytotoxicity to corneal endothelial cells in a rabbit model. J Cataract Refract Surg. 2005;31(4):792-8.

4. Chang YS, Tseng SY, Tseng SH. Comparison of dyes for cataract surgery. Part 2: efficacy of capsule staining in a rabbit model. J Cataract Refract Surg. 2005;31(4):799-804.

5. Lim AK, Ulagantheran WV, Siow YC, Lim KS. Methylen blue related sterile endophthalmitis. Med J Malaysia. 2008:63(3):249-50.

6. Brouzas D, Droutsas D, Charakidas A, Malias I, Georgiadou E, Apostolopoulos M, et al. Severe toxic effect of methylene blue $1 \%$ on iris epithelium and corneal endothelium. Cornea. 2006;25(4):470-1. 